\title{
Effect of soil moisture content on the bearing capacity of small bored piles in the unsaturated soil of Maringá, Paraná, Brazil
} \author{
Guelssi ${ }^{4}$ and Hauke Zachert ${ }^{1}$ \\ ${ }^{1}$ Technical University Darmstadt, Institute and Laboratory for Geotechnics, Darmstadt, Germany \\ ${ }^{2}$ State University of Maringá, Civil Engineering Department, Maringá, Paraná, Brazil \\ ${ }^{3}$ State University of Londrina, Londrina, Paraná, Brazil \\ ${ }^{4}$ Presidente Castelo Branco's City Hall, Castelo Branco, Paraná, Brazil
}

Verônica Ricken Marques ${ }^{1,}$, , Antonio Belincanta ${ }^{2}$, Mary-Antonette Beroya-Eitner $^{1}$, Jorge Luis Augusto Almada ${ }^{3}$, Ewerton

\begin{abstract}
In this study, the influence of soil moisture on the bearing capacity of piles founded in an unsaturated clay soil was investigated. The soil studied, composing the upper soil layer in Maringá, Brazil, is lateritic, has degree of saturation between $37 \%$ and $70 \%$ and has collapsible behaviour when wet. The bearing capacity was determined by full-scale load tests following the Brazilian Standard for Static Load Test. Two pile lengths, $4 \mathrm{~m}$ and $8 \mathrm{~m}$, were considered. To analyse the influence of soil moisture, two tests were performed for each pile length: one in soil in its natural moisture content and another in pre-moistened soil. Results show that for both pile lengths, an increase in water content caused a significant reduction in bearing capacity, which is attributed to the decrease in the matric suction of the soil. This is confirmed by the results of the initial evaluation made on the variation of matric suction and its contribution to the bearing capacity with changes in water content. In summary, this study confirms that the pile bearing capacity in unsaturated soil is dependent on soil water content, highlighting the fact that the approach of assuming full saturation condition in the evaluation of the pile bearing capacity in such soil may give erroneous results. Moreover, this study demonstrate that the empirical methods most commonly used in Brazil for pile bearing capacity determination, the Décourt \& Quaresma and Aoki \& Velloso methods, are overly conservative when applied to the Maringá soil.
\end{abstract}

\section{Introduction}

Earliest theoretical methods for determining pile bearing capacity are based on saturated soil parameters, e.g. Terzaghi [1], Vésic [2]. These methods were derived considering different failure mechanisms at the pile base and are, therefore, widely applied to tip-bearing piles. In Brazil, most of the piles used are friction piles. In addition, the said methods are considered complex and generally applicable only to purely clay or sand soils. Thus, they are generally not used in the country (Cintra and Aoki [3]).

In view of this, many Brazilian workers have tried to develop alternative methods that are more suitable for use in the country. Most of these methods are empiricallybased that relate Standard Penetration Test (SPT) and/or Cone Penetration Test (CPT) results with the bearing capacity of the piles obtained from field tests. Of these, the most commonly used are those proposed by Décourt \& Quaresma [4], which Décourt [5] later modified, and by Aoki \& Velloso [6].

Both the Décourt \& Quaresma and Aoki \& Velloso methods, hereinafter referred to as D \& $\mathrm{Q}$ and $\mathrm{A} \& \mathrm{~V}$, respectively, take into account the type of soil and pile, but the soil water content is not explicitly considered.
However, some studies show that the water content can affect the bearing capacity of piles in unsaturated soil.

Mokhberi et al. [7] carried out small-scale model laboratory tests on pile-raft, pile group, single cap, and single pile in unsaturated collapsible soil (CL/CL-ML) under different water contents. Results show that the bearing capacity of the pile-raft system and pile group decreased with increasing water content, although that of the single cap and single pile were only very marginally affected.

Chung et al. [8] investigated the bearing capacity of a small-scale model pile in unsaturated clayey soil through laboratory pile load test and numerical analysis. Results of both show a decreasing pile bearing capacity with increasing soil water content.

Tjandra et al. [9] performed a series of laboratory experiments on model pile of varying material types to investigate how the shaft capacity is affected by varying water content during the drying and wetting cycle of an expansive soil $(\mathrm{CH})$. They concluded that pile bearing capacity is differently affected by drying and wetting, but particularly during drying cycle, it generally increased with decreasing soil water content.

Sales et al. [10] field-tested two small-scale model bored piles in unsaturated sandy clay, one under natural

\footnotetext{
* Corresponding author: marques@geotechnik.tu-darmstadt.de
} 
moisture content and the other after 48 hours of flooding. They found out that the flooding caused a reduction in the bearing capacity of the pile by approximately $52 \%$.

Following the lead of these previous studies, field testing was conducted to investigate the effect of water content on the bearing capacity of piles in the unsaturated soil of the Maringá region in Brazil. In order to gain insight into how matric suction and its contribution to bearing capacity vary with changes in water content, the SWCC of the soil studied was derived using simple empirical method. Additionally, this study was aimed to verify the applicability of the D \& Q and A \& V methods to the soil of Maringá.

\section{Study area}

The study was conducted in the Experimental Geotechnical Field of the State University of Maringá, in the Maringá Region, which is located in the northwest part of Paraná State, Brazil (Fig. 1). Typical soil profile in the region consists of two layers of residual soil derived from the weathering of the basaltic basement rock.

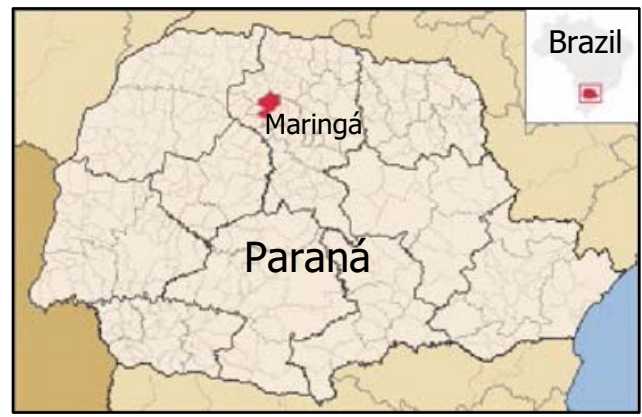

Fig. 1. Location of the study area

The upper layer is characterized by matured, lateritic silty clay with thickness that varies between $4 \mathrm{~m}$ and $12 \mathrm{~m}$ and degree of saturation from $37 \%$ to $70 \%$. The soil exhibits collapsible behaviour when wet. Below this is a less altered soil layer that can reach a depth of up to $30 \mathrm{~m}$ in some places. The soil is also silty clay but with generally lesser amount of clay fraction than the upper layer soil. Degree of saturation is from $60 \%$ to $100 \%$. Table 1 shows some of the physical properties of these soils based on the comprehensive laboratory testing program conducted in the study site by Gutierrez and Belincanta [11] and Gutierrez [12]. The groundwater table in the site is found at $15.7 \mathrm{~m}$ below the ground level.

\section{Methodology}

\subsection{Bored piles}

Bored cast in place reinforced concrete piles of lengths $4 \mathrm{~m}$ and $8 \mathrm{~m}$, with a nominal diameter of $250 \mathrm{~mm}$, were used in this study. The probable effective diameter of the piles (Table 2) was calculated from concrete consumption on installation, under the assumption that the pile length did not change and the diameter was constant during the process. Pile installation was done following the Brazilian
Standards. To analyse the influence of soil moisture, two bearing capacity tests were performed for each pile length: one under natural moisture condition and another in pre-moistened condition. Thus, a total of four bored piles were tested (Table 2).

As the soil in the study site is silty clay that exhibits cohesive behaviour when wet, the executed piles can be regarded as floating piles, i.e., only skin friction is considered significant. To further reduce base resistance, boring was made beyond the desired depth, after which the excavated loose soil was replaced up to the target depth.

Table 1. Typical physical characteristics and indices of the Maringá subsoil [11], [12]

\begin{tabular}{c|c|c}
\hline Description & $\begin{array}{c}\text { Upper } \\
\text { lateritic } \\
\text { soil }\end{array}$ & $\begin{array}{c}\text { Lower } \\
\text { residual } \\
\text { soil }^{\mathbf{1}}\end{array}$ \\
\hline Unit weight $\left(\mathrm{kN} / \mathrm{m}^{3}\right)$ & $12.5-16.5$ & $15.5-18.0$ \\
\hline Specific weight of solids $\left(\mathrm{kN} / \mathrm{m}^{3}\right)$ & $29.7-30.7$ & $28.0-30.5$ \\
\hline Natural gravimetric water content $(\%)$ & $29-35$ & $43-55$ \\
\hline Degree of saturation $(\%)$ & $37-70$ & $60-100$ \\
\hline Void ratio $(-)$ & $1.50-2.30$ & $1.25-2.00$ \\
\hline Clay fraction $(\%)$ & $52-78$ & $48-60$ \\
\hline Silt fraction $(\%)$ & $15-38$ & $26-32$ \\
\hline Fines fraction $(\%)$ & $86-95$ & $83-87$ \\
\hline Sand fraction $(\%)$ & $5-10$ & $13-17$ \\
\hline Plasticity Index $(\mathrm{PI})$ & $14-22$ & $19-40$ \\
\hline Friction angle $\left({ }^{\circ}\right)$ & $27-32$ & $22-26$ \\
\hline Effective cohesion $(\mathrm{kPa})$ & $10-30$ & $30-100$ \\
\hline Permeability coefficient $(\mathrm{cm} / \mathrm{s})$ & $10^{-3}$ & -- \\
\hline 1 Thess
\end{tabular}

${ }^{1}$ These data do not include soils close to the rock or below the water table.

\subsection{Soil pre-moistening}

As mentioned above, the bearing capacity test was conducted under natural as well as under elevated moisture conditions. Elevated moisture condition was attained by artificial pre-moistening in the case of the $4 \mathrm{~m}$ pile and by natural pre-moistening in the case of the $8 \mathrm{~m}$ pile, since the pre-moistened test on the latter pile was done after a long period of precipitation, which thereby naturally increased the soil moisture.

To determine the amount of water needed for artificial pre-moistening, historical precipitation data from the Main Weather Station of Maringá, located next to the Experimental Field, was obtained and analysed. It was noted that the biggest monthly recorded rainfall was $426 \mathrm{~mm}$, which occurred in February 1997. Monthly precipitation bigger than $400 \mathrm{~mm}$ occurred in the area only four times (Feb 1997, Jan 1990, Jan 2016 and Apr 1961) since the Station began to operate in 1961 (Águas Paraná [13]).

The area within one meter radius from the centre of the pile was considered the zone within which the amount of rain falling would influence the moisture content of the load-bearing soil. Considering this, as well as a worst rainfall scenario, i.e., biggest monthly precipitation of $426 \mathrm{~mm}$, it was estimated that approximately 1400 litres $\left(426 \mathrm{~mm} \cdot \pi \cdot 1,0 \mathrm{~m}^{2}\right)$ of water was needed for premoistening. Given the permeability coefficient of the 
upper soil layer $\left(\mathrm{k}=10^{-3} \mathrm{~cm} / \mathrm{s}\right.$, Table 1$)$, infiltration rate is estimated to be about $86 \mathrm{~cm} /$ day. Thus, the time required for infiltration of the said volume of water along the pile shaft up to some depth below the pile was calculated to be seven days.

Pre-moistening was done by first excavating away the upper $5 \mathrm{~cm}$ of the soil within the one meter radius of the pile to remove the organic layer. Then, holes about $10 \mathrm{~cm}$ in diameter and $40 \mathrm{~cm}$ in depth were drilled around the piles and filled with gravel (Fig. 2a). These holes were then covered with a ring of gravel Fig. $2 b$ ). It was assumed that the consequent disturbance of the soil did not significantly affect the pile bearing capacity. A tank with the calculated needed volume of water was put in an elevated position and the water was allowed to flow around the pile through a hose (Fig. 2c). During the seven days of soil pre-moistening, three checks per day were made to make sure that the water was continuously seeping into the soil.

For the $8 \mathrm{~m}$ pile, the pre-moistened bearing capacity test was carried out in the beginning of December 2015 and in November of that year it rained $370 \mathrm{~mm}$, the tenth biggest monthly rainfall registered in the Weather Station. Ten days prior to the test, it rained $200 \mathrm{~mm}$. The test was even interrupted in unload due to unfavourable weather conditions.

No vertical displacement of the pile has been observed after the imbibition process and before the loading tests. On the last day of each pile test, hand auger drilling was conducted to collect samples for moistened water content measurement. Sampling was done at $0.3 \mathrm{~m}$ interval up to a depth of $3 \mathrm{~m}$ to $4.5 \mathrm{~m}$, depending on the pile.
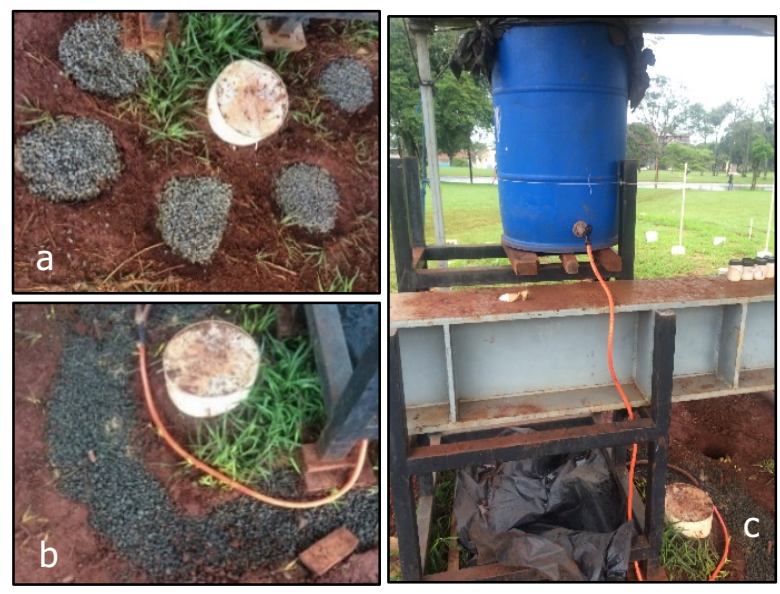

Fig. 2. Artificial pre-moistening setup. (a) Gravel-filled holes $40 \mathrm{~cm}$ in depth drilled around the pile; (b) Ring of gravels to cover the holes; (c) Water flowing around the pile through a hose.

\subsection{Bearing capacity determination}

\subsubsection{Static Load Test}

The fundamental and most reliable way to determine the bearing capacity of a pile foundation is through static or dynamic load testing. In this study, full-scale static load tests was conducted following Brazilian standard (ABNT [14]). The aim is to obtain pile load-settlement curve, which describes the behaviour of the pile as a function of loading. Details of the tests, including the load stages, duration of the test, settlement, and stabilization criterion, among others, can be found in Marques [15]. Note that no pile integrity test was conducted prior to the loading tests.

There are several methods to extrapolate the loadsettlement curve from the field data and obtain the pile bearing capacity. Among the most known and accepted, and thereby used in this study is the Van der Veen Method [16]. In this method, the load-settlement curve is assumed to follow an exponential model, as given by the following equation

$$
P=P_{R}\left(1-e^{-\alpha^{+} \cdot S^{*}}\right)
$$

where $P$ is the load on the pile; $P_{R}$ is the bearing capacity of the pile; $S$ is the settlement of the pile caused by the load $P$ and $\alpha^{+}$is a coefficient which influences the shape of the load-settlement curve. Curve fitting was performed in MATLAB $\AA$.

For comparison, the pile bearing capacity was also obtained using a common procedure in the geotechnical community, particularly in countries like the United Kingdom, Germany and Brazil. In this method, hereinafter called Conventional Method, the load corresponding to a settlement equal to $10 \%$ of the pile diameter is adopted as the bearing capacity of the pile.

\subsubsection{Empirical Methods}

The pile bearing capacity was also estimated with available empirical procedures. Specifically, the D \& Q and A \& V methods were applied using the SPT data obtained from the site (Fig. 3) in a parallel study by the present authors.

The D \& Q method is exclusively based on SPT and is widely used in Brazil. It was originally developed for precast reinforced concrete pile [4], then later on expanded for use with other pile types [5]. The pile bearing capacity, $\left(P_{R}\right)$, is taken as the sum of base resistance $\left(P_{b}\right)$ and skin friction $\left(P_{s}\right)$ :

$$
\begin{gathered}
P_{R}=\alpha^{*} \cdot P_{b}+\sum_{i=1}^{n} \beta_{i}^{*} \cdot P_{s, i} \\
P_{b}=A_{b} \cdot C \cdot N_{b} \\
P_{s}=10 \cdot\left(\frac{N_{s}}{3}+1\right) \cdot A_{s}
\end{gathered}
$$

where $A_{b}$ and $A_{s}$ are, respectively, the base and lateral pile area in $\mathrm{m}^{2} ; C$ is a coefficient for the base resistance that varies with soil type and given in $\mathrm{kPa} ; N_{b}$ is the average of the SPT N-values taken at depths immediately above and below the pile base; $N_{S}$ is the average of the Nvalues along the pile shaft; and $\alpha^{*}$ and $\beta^{*}$ are coefficients that depend on the type of pile and soil, respectively. 


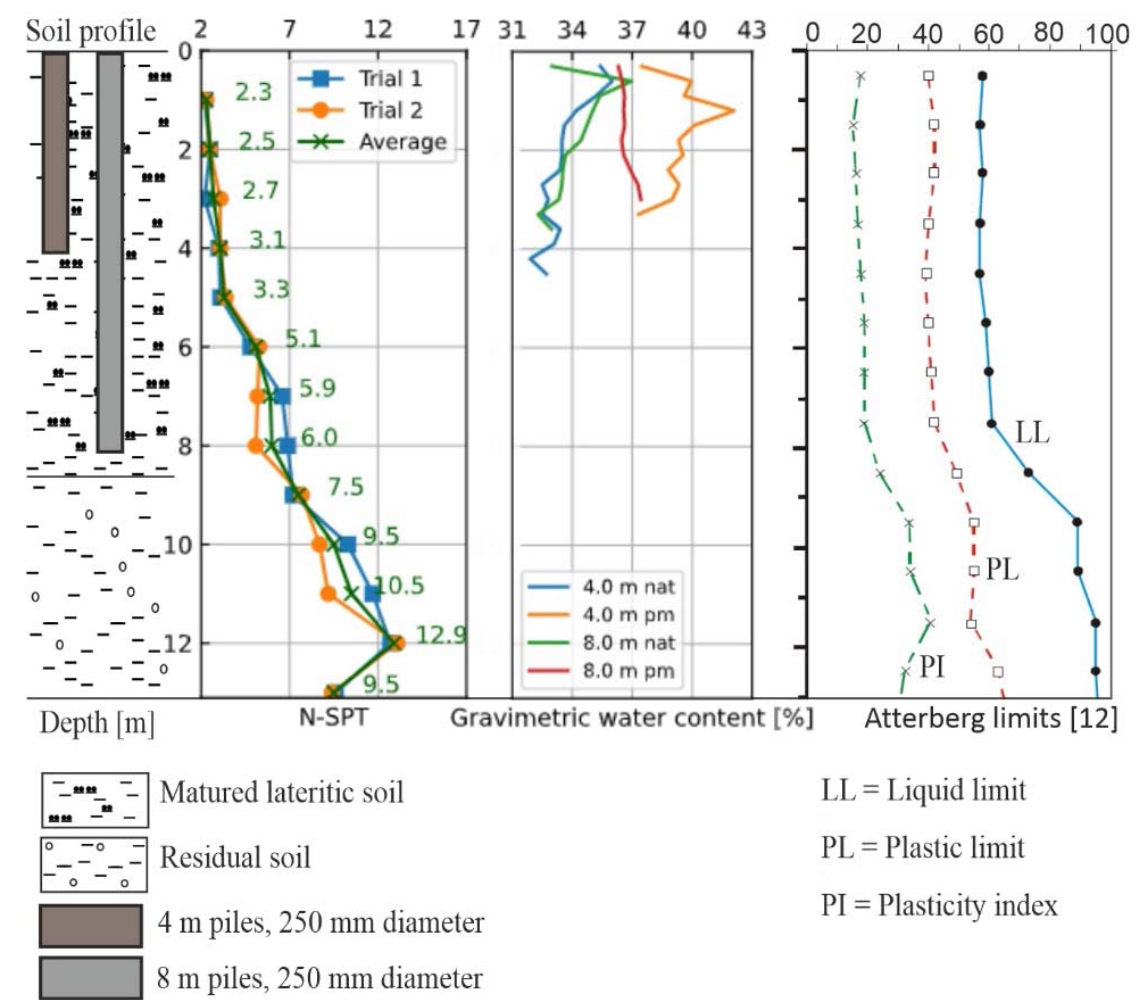

Fig. 3. SPT N-values, water content and Atterberg limits for the studied soil. The SPT- $\mathrm{N}$ values shown are the average values from the two trials. The groundwater table is found at $15.7 \mathrm{~m}$ below the ground level and is therefore not indicated.

The A \& V method, on the other hand, can either be CPT- or SPT-based. For this study, only the SPT-based is relevant. As in $\mathrm{D} \& \mathrm{Q}$, the bearing capacity $\left(\mathrm{P}_{\mathrm{R}}\right)$ is calculated as the sum of the base resistance $\left(\mathrm{P}_{\mathrm{B}}\right)$ and skin friction $\left(\mathrm{P}_{\mathrm{s}}\right)$,

$$
\begin{gathered}
P_{R}=P_{B}+P_{s} \\
P_{B}=A_{b} \cdot \frac{q_{c}}{F_{1}}=A_{b} \cdot \frac{k \cdot N_{b}^{*}}{F_{1}} \\
P_{S}=\sum_{i=1}^{n} A_{s} \cdot \frac{f_{s}}{F_{2}}=\sum_{i=1}^{n} A_{s} \cdot \frac{\alpha_{i}^{\prime} \cdot k_{i} \cdot N_{s, i}}{F_{2}}
\end{gathered}
$$

where $A_{b}$ is the pile base area; $q_{c}$ and $f_{s}$ are, respectively, the cone resistance and friction resistance from CPT test; $k$ is a coefficient that relates $q_{c}$ with SPT N-value and varies with soil type; $N_{b}^{*}$ and $N_{s}^{*}$ are the $\mathrm{N}$-value at the pile base and the average $\mathrm{N}$-value along the pile shaft, respectively; $F_{1}$ and $F_{2}$ are corrective coefficients to take into account the difference in behaviour between the pile and the cone, and vary with the kind of pile; and $\alpha^{\prime}$ is a coefficient that is a function of soil type and cone resistance.

For both the D \& Q and A \& V methods, only the skin friction was calculated since as mentioned earlier, the piles are considered floating piles.

Additionally, the bearing capacity of the piles were estimated using the $\beta$-Method so that a meaningful comparison can be made with bearing capacity calculations that explicitly take matric suction into account (Section 3.3.3). The $\beta$-Method was developed by Chandler [17], [18] and Burland [19] as an alternative to the conventional $\alpha$-Method that relates the load carrying capacity of the pile with the undrained shear strength of the soil. Contrary to the latter's total stress approach, the $\beta$-Method relates pile behaviour to effective stresses and is therefore particularly applicable where the pile is loaded at relatively slow rates such that a drained condition can be assumed, as in this study. The fact that the soil in the study site has high permeability further adds validity to such an assumption. The skin friction resistance can then be estimated using the equation,

$$
Q_{f}=\beta \cdot \sigma_{v}^{\prime} \cdot A_{s}
$$

where $\beta$ is the Burland-Bjerrum coefficient [19] and is equal to $K_{0} \cdot \tan \delta^{\prime}$, with $\delta^{\prime}$ as the effective angle of friction along the soil/pile interface and obtained by using the ratio $\delta^{\prime} / \phi^{\prime}=0.95$ proposed by Potyondy [20] for bored piles in clayey soil; $\phi^{\prime}$ is effective angle of internal friction. $\sigma_{v}^{\prime}$ is vertical effective stress at the mid-length of the pile shaft, and $A_{s}$ is lateral surface area of the pile.

\subsubsection{SWCC-based estimations}

To gain an initial insight on how matric suction and its contribution towards the bearing capacity of the piles vary with water content, the Soil Water Characteristic Curve (SWCC) of the soil in the study site was derived using the empirical procedure developed by Zapata [21] and Zapata et al. [22]. The SWCC describes the functional relationships between soil water content and matric suction, and is an important soil property fundamental for solving engineering problems associated with unsaturated soils. Adopting the analytical equation of Fredlund and 
Xing [23] for SWCC determination, Zapata [21] and Zapata et al. [22]. correlated the fitting parameters of Fredlund and Xing [23] with the parameters derived from grain size distribution (GSD) and plasticity index (PI).

The SWCC can thus be derived with the following equations:

$$
\theta_{w}=C(h) \cdot\left[\frac{\theta_{\text {sat }}}{\left[\ln \left(e+\left(\frac{\psi}{a_{f}}\right)^{n_{f}}\right)\right]^{m_{f}}}\right]
$$

with

$$
C(h)=\left[1-\frac{\ln \left(1+\frac{\psi}{h_{r}}\right)}{\ln \left(1+\frac{10^{6}}{h_{r}}\right)}\right]
$$

where $\theta_{\mathrm{w}}$ is the volumetric water content; $C(h)$ is an adjustment factor which forces the SWCC through zero water content at a suction of $10^{6} \mathrm{kPa}$; $\theta_{\text {sat }}$ is the saturated volumetric water content; $\mathrm{e}$ is the base of natural logarithm; $\psi$ is the matric suction $[\mathrm{kPa}]$; and $h_{r}, \mathrm{a}_{f}, b_{f}$ and $c_{f}$ are fitting parameters, which for plastic soils are given as follows:

$$
\begin{gathered}
a_{f}=0.00364 \cdot(w P I)^{3.35}+11 \\
m_{f}=0.0514 \cdot(w P I)^{0.465}+0.5 \\
n_{f}=m_{f} \cdot\left(-2.313 \cdot(w P I)^{0.14}+5\right) \\
h_{r}=a_{f} \cdot\left(32.44 \cdot e^{0.0186(w P I)}\right)
\end{gathered}
$$

where $w$ is the percentage passing the No. 200 sieve, given as a decimal value, and PI is the plasticity index. Note that only the SWCC for the first soil layer (up to $8.5 \mathrm{~m}$ ) was derived because all piles are bored only in this layer.

Having then obtained the SWCC, another bearing capacity calculations were made using the Modified $\beta$ Method presented in Vanapalli et al. [24] that explicitly takes matric suction into account. With this method, the shaft resistance along the pile is given by

$$
Q_{f}=\left[\beta \sigma_{v}^{\prime}+\left\{\left(u_{a}-u_{w}\right)\left(S^{\kappa}\right)\left(\tan \delta^{\prime}\right)\right\}\right] \cdot A_{s}
$$

where $\beta$ is the Burland-Bjerrum coefficient and obtained as in the original $\beta$-Method; $\sigma_{v}^{\prime}$ is vertical effective stress at the mid of the pile shaft; $u_{a}-u_{w}$ is the matric suction and obtained from the SWCC; $S$ is saturation degree: $\kappa$ is a fitting parameter that depends on the PI of the soil and is taken as 2.25 in this study following the correlation by Vanapalli and Fredlund [25]; and $A_{s}$ is the lateral surface area of the pile.

\section{Results and discussion}

In Table 2, the average natural and pre-moistened water contents of the soil for each pile length are shown. As mentioned earlier, the pre-moistened water content was obtained from samples collected by hand auger drilling, and as such could be taken only at a limited depth. For the $8 \mathrm{~m}$ pile, it was assumed that the average water content at the upper $3 \mathrm{~m}$ is representative for the entire pile depth.

As can be seen, the rain prior to the test day elevated the moisture content from $34.1 \%$ to $36.7 \%$. Meanwhile, a value of $39.4 \%$ was attained with artificial premoistening, from a natural moisture content of $33.6 \%$. Since the artificial pre-moistening was based on the worst rainfall scenario, this higher moisture content is expected. Changes in water content is more uniform with natural pre-moistening, varying only from $36.3 \%$ to $37.4 \%$, as compared to $37.1 \%$ to $41.9 \%$ with artificial premoistening. Again, this is expected considering that the former was obtained after a rainy month; the water thus has more time to infiltrate into the soil.

Figure 4 shows the load-settlement curve derived using the Van der Veen Method for both pile lengths under the two different moisture conditions. The bearing capacity values obtained with the said method as well as those obtained with the Conventional Method are also indicated. As can be seen, the two methods yielded the same bearing capacity values. Since the piles have different effective diameter, it was necessary to normalize

\begin{tabular}{|c|c|c|c|c|c|c|c|c|c|c|}
\hline Pile & $\begin{array}{l}\text { Pile } \\
\text { length } \\
\text { (m) }\end{array}$ & $\begin{array}{c}\text { Effective } \\
\text { diameter } \\
(\mathbf{m m})\end{array}$ & $\begin{array}{c}\text { Water } \\
\text { content } \\
(\%)\end{array}$ & $\begin{array}{c}\text { S (\%) } \\
\text { Average } \\
\text { (minimum) }\end{array}$ & $\begin{array}{c}\text { Suction } \\
\text { (kPa) } \\
\text { Average } \\
\text { (minimum) }\end{array}$ & $\begin{array}{c}\text { Field } \\
\text { based }^{4}\end{array}$ & $\begin{array}{c}\text { D\&Q } \\
(\mathrm{kN})\end{array}$ & $\begin{array}{c}\text { A\&V } \\
(k N)\end{array}$ & $\begin{array}{c}\beta \text {-Method } \\
(\mathrm{kN})\end{array}$ & $\begin{array}{c}\text { Modified } \beta \text { - } \\
\text { Method } \\
\text { (kN) } \\
\text { Average } \\
\text { (Minimum) }\end{array}$ \\
\hline $\mathrm{P} 4 \mathrm{n}^{1}$ & 4 & 260 & 33.6 & $\begin{array}{c}53.4 \\
(68.8) \\
\end{array}$ & $\begin{array}{c}813.5 \\
(190.1) \\
\end{array}$ & 118.3 & \multirow{2}{*}{47.0} & \multirow{2}{*}{21.3} & \multirow{2}{*}{24.6} & $\begin{array}{c}343.5 \\
(126.6) \\
\end{array}$ \\
\hline $\mathrm{P} 4 \mathrm{p}^{2}$ & 4 & 285 & 39.4 & $\begin{array}{c}62.5 \\
(80.4)\end{array}$ & $\begin{array}{l}442.6 \\
(90.2)\end{array}$ & 83.6 & & & & $\begin{array}{l}268.6 \\
(90.6)\end{array}$ \\
\hline $\mathrm{P} 8 \mathrm{n}^{1}$ & 8 & 285 & 34.1 & $\begin{array}{c}54.2 \\
(69.8)\end{array}$ & $\begin{array}{c}768.9 \\
(178.5) \\
\end{array}$ & 249.8 & \multirow{2}{*}{114.5} & \multirow{2}{*}{62.6} & \multirow{2}{*}{98.5} & $\begin{array}{c}595.4 \\
(266.8) \\
\end{array}$ \\
\hline$P 8 p^{3}$ & 8 & 260 & 36.7 & $\begin{array}{c}58.3 \\
(75.1)\end{array}$ & $\begin{array}{c}579.4 \\
(128.3)\end{array}$ & 216.4 & & & & $\begin{array}{c}623.5 \\
(234.3)\end{array}$ \\
\hline
\end{tabular}
the obtained values to a reference diameter, which in this case is the nominal diameter of $250 \mathrm{~mm}$. As the bearing capacity of the piles was taken to be due only to skin friction, it can easily be recalculated to a normalized value.

Table 2. Bearing capacity obtained from different methods for both pile lengths

${ }^{1}$ Natural water content; ${ }^{2}$ Artificially pre-moistened; ${ }^{3}$ Naturally pre-moistened (after long rainfall period); ${ }^{4}$ From Van der Veen and Conventional Methods. 

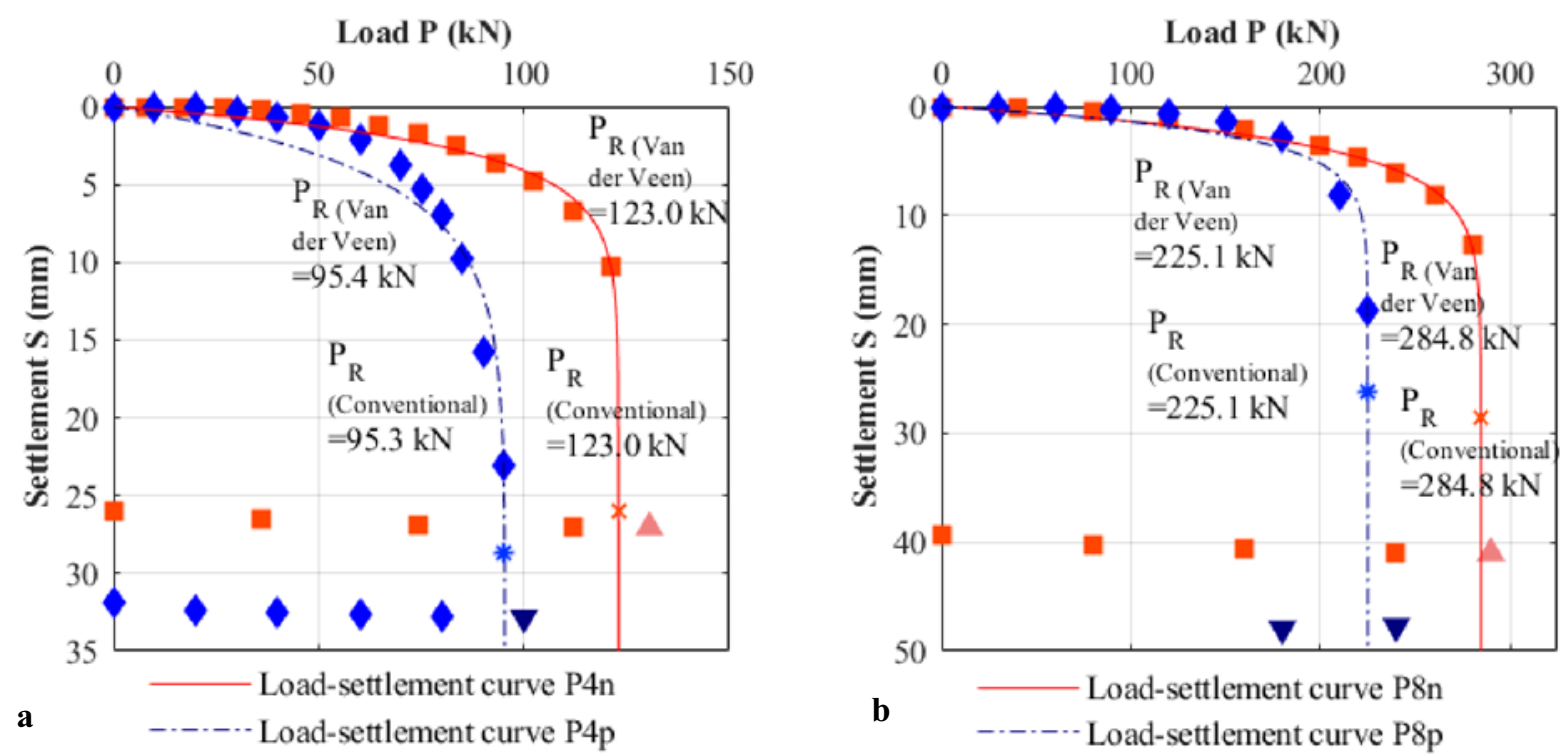

Fig. 4. Comparison of load-settlement curves under natural moisture and pre-moistened water contents for (a) $4 \mathrm{~m}$ piles; (b) $8 \mathrm{~m}$ piles.

Table 2 summarizes the normalized bearing capacity obtained from all methods for both pile lengths and moisture conditions. Note that for the D \& Q, A \& V, and the original $\beta$-Method, a unitary value is given for both moisture conditions since these methods do not explicitly take water content into account. For the Modified $\beta$-Method, both the average and minimum values are given based on the average and minimum SWCC shown in Figure 5a and on the average and minimum (or maximum, where appropriate) values of the relevant parameters in Table 1. The variation of bearing capacity with matric suction for each pile are also shown in Figure $5 b$.

As can be clearly seen from the static load test results, the moisture condition has a strong influence on pile bearing capacity. For instance, for the $4 \mathrm{~m}$ pile, premoistening the soil caused a $29.3 \%$ reduction in bearing capacity. It is worthwhile to note that such a pile type and size is widely used in Maringá region, especially for small and medium sized buildings (Belincanta and Branco [26]). For the $8 \mathrm{~m}$ pile, natural pre-moistening only increased the soil moisture content by $2.6 \%$, compared to a $5.8 \%$ increase with artificial moistening. This is therefore consistent with a smaller degree of bearing capacity reduction of only $13.4 \%$ in this pile. It is also possible that the rainwater had not yet infiltrated into the full depth of the pile during the test, further contributing to this lower degree of reduction. Other factors that might have affected the obtained bearing capacity values for both pile lengths are the possible inconstant diameter throughout the entire pile length as a result of borehole cave-in during drilling, as well as change in pile length due to compaction of the underlying loose soil. The effects of these last two factors are however considered insignificant.
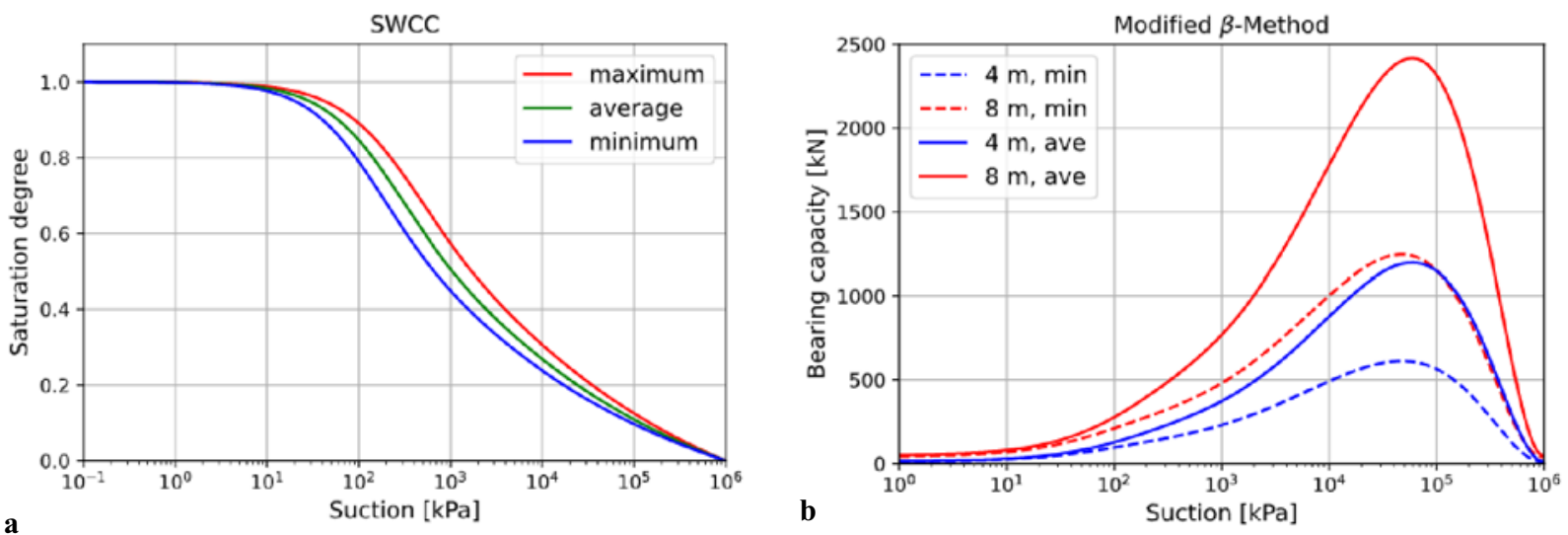

Fig. 5 (a) SWCC for the first soil layer obtained using the soil index property-based method developed by Zapata [21] and Zapata et al. [22] and (b) Variation of bearing capacity with matric suction as obtained using the Modified $\beta$-Method of Vanapalli et al. [24] 
Since the soil in the studied depth is unsaturated, the general decrease in bearing capacity with increased water content is attributed to the decrease in matric suction, as the result of the Modified $\beta$-Method also indicated. Matric suction is generally understood as a pore-water pressure with negative value with respect to the pore-air pressure. For unsaturated soils, Fredlund and Morgenstern [27] introduced a fourth phase, termed contractile skin, in addition to air, water and solid phases. As Rahardjo et al. [28] explained, this contractile skin acts like an elastic membrane that pulls the soil particles together through surface tension when matric suction increases, which then impart additional strength to the soil. With increased water content, matric suction decreases, resulting to reduced soil strength. This could explain why those empirical methods as the D \& Q, A \& V and the original $\beta$-Method that do not explicitly take into account water content and its concomitant effect to matric suction tend to underestimate bearing capacity.

As observed in Table 2, although the results of the Modified $\beta$-Method generally agree with the expectations of decreasing bearing capacity with decreasing matric suction, the method appears to grossly overestimate the result of the field tests. There may therefore be a need to review and improve this method in future studies, particularly as it was developed from limited empirical data. Finally, it can be seen in Figure 4 that as compared to that in pre-moistened condition, curve fitting with the Van der Veen model is better for the data under natural moisture content condition. Adding a coefficient that is a function of water content may result in a better fitting curve, which is important for assessing pile behaviour during loading.

\section{Summary and conclusion}

Many shallow foundation and short-pile bearing strata are in an unsaturated state, yet the bearing capacity of these strata is commonly evaluated assuming fully saturated conditions. In this study, we investigated the influence of soil moisture content on the behaviour of small bored piles in unsaturated soil. The study site is located in Maringá region, where this type of pile is in common use and is almost always founded on unsaturated soil.

Results show that the pile bearing capacity can significantly decrease even with just a small increase in soil moisture content, which is attributed to the decrease in matric suction. This highlights the problem of ignoring the influence of water content and therefore of matric suction, in pile bearing capacity determination. As pointed out above, matric suction imparts additional strength to the soil, which increases with decreasing soil saturation degree. Thus, a static load test conducted during dry season may yield a high bearing capacity that may not hold during wet season. In reverse, ignoring the contribution of matric suction may lead to over-design and excessive costs.

Results of this study also show that the empirical methods commonly used in Brazil are overly conservative and may not be applicable to Maringá soil. A new empirical method needs to be developed that take into account soil moisture content and its relationship with matric suction. This study contributes to the database for such an effort.

\section{Acknowledgement}

This work was supported by CAPES (Coordination for the Improvement of Higher Education Personnel).

\section{References}

1. K. Terzaghi. (1943). Theoretical soil mechanics. John Wiley and Sons. New York.

2. A. B. Vesic. (1963). Bearing capacity of deep foundations in sand. Washington, D.C., pp. 112153.

3. J. C. A. Cintra and N. Aoki. (1999). Carga admissivel em fundações profundas. EESC/USP. São Carlos.

4. L. Décourt and A. R. Quaresma. (1978). Capacidade de carga de estacas a partir de valores de SPT. Rio de Janeiro, COBRAMSEG, 6. 1, pp. 45-53.

5. L. Décourt. (1996). A ruptura de fundações avaliada com base no conceito de rigidez. SEFE, São Paulo, 1, pp. 215-224.

6. N. Aoki and D. A. Velloso. (1975). An approximate method to estimate the bearing capacity of piles. Buenos Aires, PASSMFE, 5, pp. 367-374.

7. M. Mokhberi and S. A. Rafieeian. (2019). The piled-raft behavior installed in unsaturated collapsible soils. Arab. J. Geosci., 12, no. 2, p. Article 49.

8. S.-H. Chung and S.-R. Yang. (2017). Numerical Analysis of Small-Scale Model Pile in Unsaturated Clayey Soil. Int. J. Civ. Eng., 15, no. 6, pp. 877-886, doi: 10.1007/s40999-016-00657.

9. D. Tjandra, I. Soemitro, and R. A. A. Soemitro. (2014). The Influence of Water Content Variations on Friction Capacity of Piles in Expansive Soil. Int. J. ICT-Aided Archit. Civ. Eng., 1, no. 1, pp. 31-40.

10. M. M. Sales, R. P. Cunha, M. M. Farias, and J. H. F. Pereira. (2001). Efeito da pré-inundação nos resultados de provas de carga de sapatas e estacas na argila porosa de Brasília. Rio de Janeiro, NSAT vol. único, pp. 399-416.

11. N. H. M. Gutierrez and A. Belincanta. (2004). Características básicas dos solos constituintes do subsolo da cidade de Maringá: locais de alta e média vertente. Curitiba, GEOSUL 1, pp. 39-46.

12. N. H. M. Gutierrez. (2005). Influências de aspectos estruturais no colapso de solos do norte do Paraná. Universidade de São Paulo - USP, São Carlos, São Paulo, Brazil.

13. Águas Paraná. (2021). Alturas diárias de precipitação (mm). [Online]. Available: http://www.aguasparana.pr.gov.br/pagina264.html. 
14. Associação Brasileira de Normas Técnicas. (2010). ABNT NBR 12131: Estacas - prova de carga estática. ABNT.

15. V. R. Marques. (2017). Uma contribuição ao entendimento da capacidade de carga de estacas escavadas, sem fluido estabilizante, em solo típico da cidade de Maringá/PR. Universidade Estadual de Maringá, Maringá.

16. C. Van der Veen (1953). The Bearing Capacity of a Pile. Zurich, 3rd International Conférence on Soil Mechanics and Foundation Engineering 2, pp. 84-89.

17. R. J. Chandler. (1966). Discussion. ICE Conference on Large Piles Proc., London, pp. 95-97.

18. R. J. Chandler. (1968). The shaft friction of piles in cohesive soils in terms of effective stress. Civ. Eng Public Works Rev. UK, vol. 60, no. 708, Accessed: Feb. 10, 2021. [Online]. Available: https://trid.trb.org/view/121929.

19. J. Burland. (1973). Shaft friction of piles in clay - A simple fundamental approach. Ground Eng., 6, pp. 30-42.

20. J. G. Potyondy. (1961). Skin Friction between Various Soils and Construction Materials. Géotechnique. 11, no. 4, pp. 339-353, doi: 10.1680/geot.1961.11.4.339.

21. C. Zapata. (1999). Uncertainty in soil-water characteristic curve and impacts on unsaturated shear strength predictions. $\mathrm{PhD}$, Arizona State University, Tempe, AZ.

22. C. Zapata. (2000). W. Houston, S. Houston, and K. Walsh. Soil-Water Characteristic Curve Variability, Geo-Denver. 287, p. 124.

23. D. G. Fredlund and A. Xing. (1994). Equations for the soil-water characteristic curve. Can. Geotech. J., 31, pp. 521-532.

24. S. Vanapalli, K. D. Eigenbrod, Z. N. Taylan, C. Catana, W. Oh, and E. Garven. (2010). A technique for estimating the shaft resistance of test piles in unsaturated soils. 5th International Conference on Unsaturated Soils. 2. doi: 10.1201/b10526-188.

25. S. K. Vanapalli and D. G. Fredlund. (2000). Comparison of Different Procedures to Predict Unsaturated Soil Shear Strength. Advances in Unsaturated Geotechnics, Denver, Colorado, United States, pp. 195-209, doi: 10.1061/40510(287)13.

26. A. Belincanta and C. J. M. C. Branco. (2003). Fundações em Londrina e em Maringá: uma síntese histórica. Maringá, ENGEOPAR 1, pp. 266-278.

27. D. G. Fredlund and N. R. Morgenstern. (1977). Stress state variables for unsaturated soils. J. Geotech. Geoenvironmental Eng., 103, pp. 447466, 1977.

28. H. Rahardjo, Y. Kim, and A. Satyanaga. (2019). Role of unsaturated soil mechanics in geotechnical engineering. Int. J. Geo-Eng., 10, no. 1, p. 8, Dec. doi: 10.1186/s40703-019-01048 . 